\title{
Estimating the inhibitory effect of Lactobacillus isolated from different sources on some pathogens of urogenital infections in women group
}

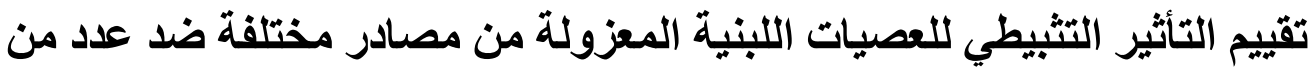

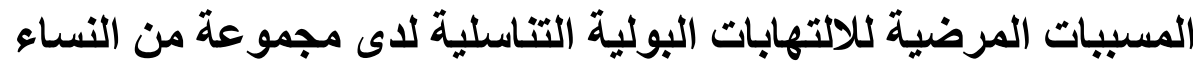

Bushra J .Mohamed Amina N. AL. Thwani

Genetic Engineering and Biotechnology Institute for Postgraduate Studies/ University of Baghdad

$$
\text { معهد الهندة الور اثية و الثقنيات الاحيائية للار اسات العليا / جامعة بغد نعمد الثويني }
$$

\section{Abstract}

This study was aimed to identify of pathogenic organism isolated from urogintal tract and estimate the effect of Lactobacillus which isolated from different sources on the growth of these pathogens including (Candida albicans, Staphylococcus aureus, Escherichia coli, Pseudomonas aeruginosa, Gardnerella viginals, Klebsiella oxytoca, Proteus mirabilis). The results showed that Lactobacillus which was isolated from vagina on solid medium was effective against pathogenic isolates more than the Lactobacillus species isolated from yoghurt, cow milk, human milk with inhibition zone (12-16) $\mathrm{mm}$, while the highs inhibitory effect of Lactobacillus isolated from vagina in liquid media with inhibition zone reached to(18)mm. Adversely, lowest inhibitory effect was shown with supernatant of Lactobacillus spp. isolated from human milk with inhibition zone reached to (11)mm comparison with Lactobacillus spp. isolated from yoghurt and cow milk with inhibition zone (13-15) $\mathrm{mm}$. Also the result revealed that Lactobacillus spp. isolated from vagina, human milk, cow milk and yoghurt by overlay method had no effect on pathogenic bacteria but high effect was shown only with the vaginal Lactobacillus isolates on C. albicans.

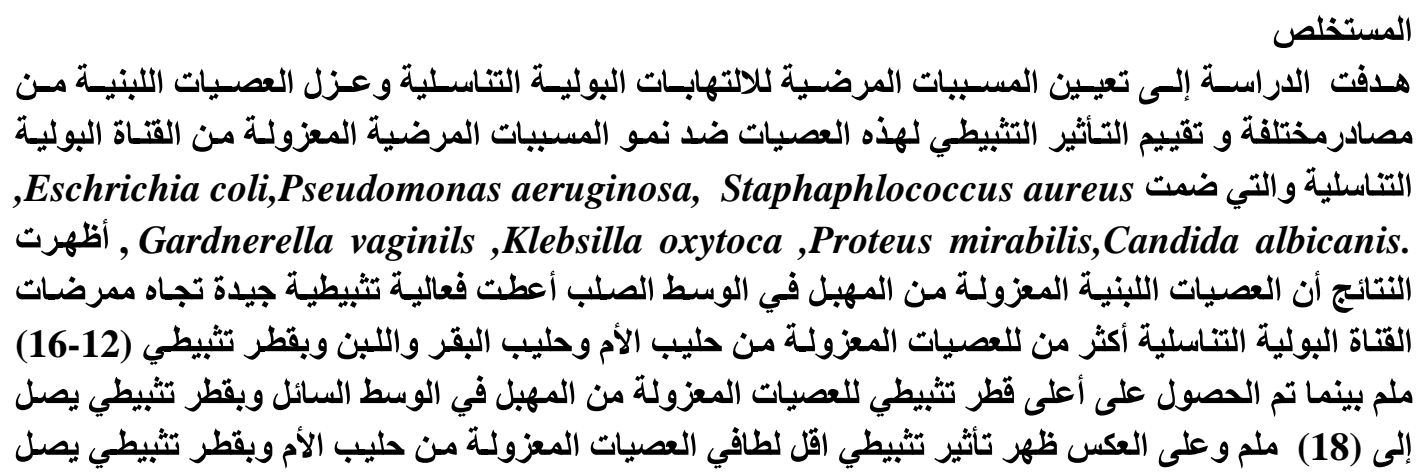




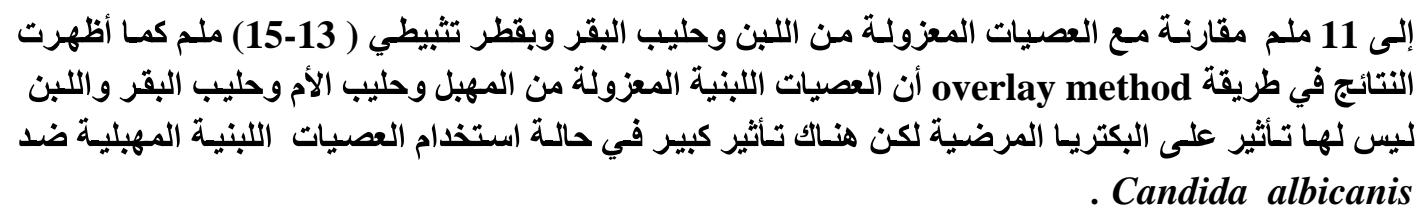

\section{Introduction}

Although antimicrobial therapy is generally effective in eradicating urogintal infections, there is still a high incidence of recurrence [1]. Patient's quality of life is affected and many women become frustrated by the cycle of repeated antimicrobial treatment whose effectiveness is diminishing due to increasing development of microbial resistance [2]. So, need for alternative treatment encouraged the researchers for seeking to reach the best outcome [3]. Use of Lactobacillus in such cases appears to be a promising answer as a current challenge experienced due to excessive and misuse of antibiotics. Lactobacillus is used in urogenital tract infections to re-establish the vaginal flora and prevent future episodes, bacterial vaginitis, vaginal Candidiasis, recurrent UTI, bladder cancer and complications of antibiotic therapy [4]. Because of their relative safety, ease of use, and excellent tolerability, the use of Lactobacillus should be considered, not just as adjunctive replacement after antibiotic administration, but as possible first-line therapy when clinically indicated.

This study was designed to isolate and identify of pathogens from urogintal infection, selecting Lactobacillus from human and food sources and estimating the effect of these organisms on the growth of pathogens recovered from urogenital women patients.

\section{Material and methods}

\section{Isolation and identification of pathogens:}

\section{From vaginal swabs}

Two vaginal swabs from 250 patients were transported to the laboratory by inoculating the swab into a sterile tube containing $3.0 \mathrm{ml}$ of saturate transport medium (Sabourauds dextrose broth or Brain heart infusion broth/ Difco- USA). One of the swabs was directly inoculated onto each of Sabourauds dextrose agar (Difco- USA), Blood agar (Oxoid- England) and MacConkey agar (Difco- USA) for microbiological investigation. The other was used for direct examination by wet mounted film and Gram stained for detection of yeasts and bacteria. Inoculated culture plates were incubated at $37^{\circ} \mathrm{C}$ for 24 72 hrs. Colonies were identified by morphological and biochemical tests and motility test was also preformed. Stock culture was made by inoculating single colony of the isolates into a slant of Sabourauds dextrose ager (for yeast) and Nutrient agar (for bacteria).

\section{From urine sample [5].}

Urine samples $(20-45 \mathrm{ml})$ were collected in sterile glass containers of $50 \mathrm{ml}$ volume by using mid stream specimens method, mid stream urine samples were taken after cleaning the genital area with soap and water, The sample was divided into two parts , one used for microscopic examination, and the other for culturing. 


\section{Microscopical examination of urine sample [5].}

By using portable centrifuge (Buch- Germany), $10 \mathrm{ml}$ of urine was centrifuged at 3000 rpm for $5 \mathrm{~min}$, then the supernatant was discarded and one drop of the retained sediment in the centrifuge tube was placed on glass slide, and covered by cover slip, then examined under the power $40 \mathrm{x}$.

\section{Culturing the urine sample [6].}

Quantization of organism in urine was done by using full loop inoculation. A volume of $0.001 \mathrm{ml}$ of human urine was spreaded on enriched media (blood agar) and selective media (MacConky agar). The samples were incubated at $37^{\circ} \mathrm{C}$ for $24 \mathrm{hr}$. After that the number of bacterial colonies on the agar was calculated and the number of organism in I $\mathrm{ml}$ of urine was measured.

\section{Identification of yeasts}

Yeasts isolates were identified through the following steps as described by [7].

1. Gram stain [8].

Small portion of yeast colony was transferred by sterile loop, smeared and fixed on microscopic slide for staining by Gram stain to examine cells shape, grouping and reaction.

\section{Production of chlamydospores [9].}

Corn meal agar medium was inoculated with single colony of the isolated yeast. Inoculation was done by making 3-6 parallel cuts of $1 \mathrm{~cm}$ in length on surface of the media, the streaks were covered by a sterile cover slip the inoculated plates were incubated at $28^{\circ} \mathrm{C}$ up to 2 days. Examination of plates for the presence of chlamydospores was done under microscope.

\section{Production of germ tube [10].}

A small portion of the isolated colony was emulsified in one $\mathrm{ml}$ of sterile human serum, then incubated for $2-3 \mathrm{hrs}$ at $37^{\circ} \mathrm{C}$, one drop of the suspension was placed on clean slide with drop of lactophenol cotton blue then examined microscopically for the production of germ tube.

4. Biochemical tests including :

\section{A. Sugar fermentation test [11].}

A set of sugars consists of glucose, lactose, maltose and sucrose, which were used for identification and differentiation between Candida species. The test was done by inoculating tubes containing fermentation media and $2 \%$ sugar with part of the colony, shaking gently then incubated at $28-30^{\circ} \mathrm{C}$ for three days .The positive result was recorded by changing the color of bromocrysol puraple indicater to yellow and production of $\mathrm{CO}_{2}$ gas bubbles in Durham tube.

\section{B. Carbohydrate assimilation test [11].}

The test depends on the ability of different species of yeasts to grow in various sugar solutions (glucose, lactose, trehalos, raffinose and sucrose). Carbohydrate assimilation medium was poured in Petri dishes and inoculated with Candida spp ,then six wells were made by cork borer in the inoculated plates, each well were filled with $2 \%$ sugar and incubated plates at $30^{\circ}$ for 2-4 days. 


\section{Identification of bacteria}

The isolated bacteria were identified according to $[12,13,14,15,16]$ by using Gram stain and biochemical tests Including: - oxidase, indole, catalase, urea hydrolysis, geletinase, kiliglar iron agar, coagulase, phenylalnine deaminase, motility and Whiff test, Carbohydrates fermentation test (glucose, sucrose, maltose, mannitol ,rafenose ,lactose, trehalose, rhaminose, arabinose, fructose, galactose, sorbitol, salicin, cellobose, ribose, melibiose,mannose and xilose) growing at $45^{\circ} \mathrm{C}$, production of ammonia from arginin, acid and cured production from litmus milk.

\section{Isolation of Lactobacillus}

\section{From vagina}

Lactobacillus isolates were isolated from vaginal swabs, samples of the 80 women attended obstetric and gynecology clinics of Fatima AL-Zahra hospital in Baghdad. The samples were inoculated in $10 \mathrm{ml}$ MRS broth (Oxoid- England) then cultured onto MRS agar (Oxoid- England) of $\mathrm{pH} 5.2$ and incubated at $37^{\circ} \mathrm{C}$ for 48 hour, followed by subculturing onto MRS agar of $\mathrm{pH} 4.3$ at $37^{\circ} \mathrm{C}$ in a candle jar for 48 hour. Lactobacilli were identified on the basis of growth on selective MRS agar, colony morphology, Gram staining, catalase activity, beside motility test and other biochemical testes Further identification of the species of the Lactobacilli was performed by carbohydrate fermentation test, growth at $15^{\circ} \mathrm{C}$ and $45^{\circ} \mathrm{C}$ in MRS broth according to [12,14].

\section{Isolation of Lactobacillus from human milk.}

Seven samples $(2-5 \mathrm{ml})$ of human milk were taken from breasts healthy women and put into $10 \mathrm{ml}$ MRS broth. The Lactobacilli were identified according to [12, 14].

\section{From cow milk and yoghurt}

Lactobacillus isolates were obtained from six samples of cow milk and yoghurt: one sample of yoghurt was home made from cow milk, two samples from retail markets, one sample was dried cow milk and two samples was fresh cow milk. The isolation was performed by the routine microbiological procedure mention above according to [12 ,14].

\section{Determining inhibitory effect of Lactobacillus spp. on pathogenic organisms On sold medium (MRS Agar)}

Culture of Lactobacillus previously grown in MRS broth was streaked on MRS agar plate and then plates were incubated under anaerobic condition at $37^{\circ} \mathrm{C}$ for $18 \mathrm{hr}$.

[17]. A cork borer (5mm diameter) was used to withdraw disks of Lactobacillus growth which were incubated and put on surface of Sabourauds dextrose agar and Nutrient agar that was inoculated previously with $0.1 \mathrm{ml}$ of yeast or bacteria suspensions then incubated at $37^{\circ} \mathrm{C}$ for $24 \mathrm{hr}$, the inhibition zones around the disk were estimated in millimeter.

\section{In liquid medium (MRS broth)}

MRS broth was inoculated with $1 \%$ of Lactobacillus isolates then incubated at $37^{\circ} \mathrm{C}$ for $18 \mathrm{hr}$. [18] After incubation, the culture was centrifuged at $6000 \mathrm{rpm}$ for $15 \mathrm{~min}$, and 
filtered through millipor filter unit $(0.22 \mathrm{um})$.According to well diffusion method that mentioned by [19]. Sabourad and Nutrient agar plates were inoculated with $0.1 \mathrm{ml}$ of each pathogenic organism ( $C$. albicans, G. vaginalis,Staph.aureus $P$. aeruginosa, E.coli,Klebsiella oxytoca or Proteus mirabilis) by a spreader then ,5mm wells were made by the cork borer. Each well was filled with Lactobacillus supernatant, then incubated at $37^{\circ} \mathrm{C}$ for $24 \mathrm{hr}$. Inhibition zones around the wells were measured by (mm) and compared with that of control which contained MRS broth only.

Agar overlay method [19].

Lactobacillus was cultured on MRS agar and incubated at $37^{\circ} \mathrm{C}$ for $18 \mathrm{hr}$ and a thin layer of Nutrient agar (Oxoid- England) was poured over it and keept at $4^{\circ} \mathrm{C}$ for $2 \mathrm{hr}$, then incubated at $37^{\circ} \mathrm{C}$ for $48 \mathrm{hr}$ after pathogenic organism was streaked on the surface of agar.

\section{Results and discussion}

From a total of vaginal swabs examined $(32.81 \%)$ were identify C.albicans, followed by (16.14\%) Staph .aureus then (10.93\%) E.coli, (9.37\%) P. aeruginosa, (5.72\%) Klebsiella oxytoca, (5.20\%) G. virginals and (3, 12\%) Proteus mirabilis.

In the urine samples E.coli was the common pathogen with percentage of $(26.29 \%)$ followed by Staph.aureus (24.13\%), C.albicans (20.68\%), such percentage were very high when compared to other microorganisms ( P. aeruginosa (9.91\%), G.viginals (4.31\%), Klebsiella oxytoca. $(3.01 \%)$ and Proteus mirabilis ( $2.58 \%)$ this observation come in accordance with [20and 21] who found that all above pathogens were highly present in female urogenital tract.

\section{Identification of Lactobacillus bacteria}

Suspected colonies appeared, pale, round, convex, soft,mucoid and surrounded by zone as a result of dissolving calcium carbonate. When part of the colonies were examined microscopically cells appeared Gram positive bacilli, mainly grouped in chains containing 3-8 cells, and non-sporformers. Biochemical tests showed positive results to lactose fermentation, growth at $45{ }^{\circ} \mathrm{C}$ and $15{ }^{\circ} \mathrm{C}$. Furthermore, curd formed in litmus milk, while gave negative result to catalase ,oxidase ,urease , motility and production of NH3 from arginine. These results come in concord with those obtained by [16, 22].

\section{Inhibitory effect of Lactobacillus on pathogenic organisms On solid medium (MRS agar)}

Result revealed that propagation of Lactobacillus isolates on MRS agar under anaerobic condition was an efficient method for producting of their inhibitory metabolites against tested pathogens. In this approachAl-Kafaji [17] found that using MRS agar medium in studying the ability of Lactobacillus isolates to produce inhibiting materials under anaerobic condition, if the chosen procedure that gives reasonable result.

Our finding revealed that Lactobacillus isolated from vagina was effective against pathogenic isolates and had the best effect which clarified by the zone of inhibition growth for pathogenic isolate, which ranged between (16-12) $\mathrm{mm}$, while the less effect 
was observed when Lactobacillus isolates from yoghurt, cow milk, human milk were used as shown in table (1) .

Table (1): Inhibitory effect of Lactobacillus spp. isolated from different sources, on pathogenic microorganisms expensed as diameter of inhibition zones (mm) .

\begin{tabular}{|c|c|c|c|c|c|c|c|}
\hline $\begin{array}{c}\text { Code of } \\
\text { Lactobacillus }\end{array}$ & E.coli & Staph.aureu & P.aeruginos & G.vaginali & K.oxytoca & P.mirabilis. & C.albecanis \\
\cline { 2 - 8 } & \multicolumn{7}{|c|}{ Diameter /mm } \\
\hline Lb.1 & 16 & 16 & 12 & 14 & 13 & 13 & 14 \\
\hline Lb.2 & 14 & 15 & 10 & 12 & 10 & 11 & 12 \\
\hline Lb.3 & 11 & 11 & 9 & 11 & 11 & 10 & 9 \\
\hline Lb.4 & 8 & 9 & 5 & 7 & 5 & 8 & 12 \\
\hline
\end{tabular}

Lb.1=Lactobacillus from vaginal swab, Lb.2= Lactobacillus from yoghurt, Lb.3= Lactobacillus from cow milk , Lb.4= Lactobacillus from human milk

Our finding indicated that Lactobacillus isolated from vagina possessed the highest inhibitory effect among other isolates, because it has the same ecosystem of pathogens. Therefore, produced variety of compounds with antimicrobial activity and the end products during Lactobacillus fermentation, causing a reduction in $\mathrm{pH}$ [23]. These finding come in accordance with those other workers [24, 25].

\section{In liquid Media (MRS broth)}

Inhibitory effect of Lactobacillus isolates grown in MRS broth was evaluated also .Well diffusion method was used to determine the inhibition activity of Lactobacillus against pathogenic isolates. Highs inhibitory effect was obtained during using supernatant of Lactobacillus isolated from vagina, the inhibition zones reached to $18 \mathrm{~mm}$. Adversely, lowest effect appeared with supernatant of Lactobacillus isolated from human milk when the inhibition zone reached only $11 \mathrm{~mm}$.While Inhibitory effect of Lactobacillus isolates recovered from yoghurt and cow milk ranged between( 13-15) as shown in table (2).

Table (2): Inhibitory effect of Lactobacillus spp isolated from different sources on pathogenic microorganisms which was measured by millimeter (In MRS broth).

\begin{tabular}{|c|c|c|c|c|c|c|c|}
\hline $\begin{array}{c}\text { Code of } \\
\text { Lactobcillus }\end{array}$ & E.coli & Staph.aureus & P.aeruginosa & G.vaginalis & Koxytoca & P.mirabilis & C.albecanis \\
\cline { 2 - 8 } & \multicolumn{7}{|c|}{ Diameter/m.m } \\
\hline Lb.1 & 18 & 18 & 17 & 16 & 15 & 14 & 14 \\
\hline Lb.2 & 15 & 15 & 14 & 15 & 14 & 15 & 14 \\
\hline Lb.3 & 13 & 12 & 10 & 12 & 11 & 10 & 12 \\
\hline Lb.4 & 11 & 9 & 9 & 11 & 9 & 8 & 9 \\
\hline
\end{tabular}

Lb.1=Lactobacillus from vaginal swab, Lb.2= Lactobacillus from yoghurt, Lb.3= Lactobacillus from cow milk, Lb.4= Lactobacillus from human milk 
Maximum inhibition zone was obtained from vaginal Lactobacillus isolates, which were grown in MRS broth, in comparison to those grown on solid medium, it was obvious that MRS broth was a better stimulator for inhibitory product than MRS agar .Such finding was confirmed by Fang et al [26] who mention that MRS broth stimulated inhibitory effect against Gram positive (Staph. aureus) and Gram negative bacteria ( E.coli ,Klebsiella spp.,Proteus spp.) Similar results were also obtained by Kubba [27] who found that best inhibitory effect was gained when liquid media (MRS broth) was used to estimate the effect of Lactobacillus on pathogenic bacteria.

\section{Overlay method}

The target of this method was to test the ability of Lactobacillus bacteria for inhibiting growth of pathogenic organism by the effect of substance diffused in agar. Results showed that Lactobacillus isolated from vagina, human milk, cow milk and yoghurt had no effect on pathogenic bacteria but there was a slight effect on Candida. High effect was exhibited only when the vaginal Lactobacillus isolates were used on Candida. This inhibition indicates presence of antimicrobial substances in Lactobacillus grown on agar which absence of such effect in this method on most pathogen may be related to high molecular weight substances that can not diffuse through the agar [28]. Similar observation were recorded by other investigators [29 - 30].

\section{References}

1. Ronald, A.R. (2002).Infections of upper urinary tract .Ch.34,In: Disease of the kidney, $6^{\text {th }}$ ed.,Vol.1,eds:Robert W. Schriery and Carl W. Gottschalk.permission of Harper and Row publishers ,Inc. U.S.A.

2. Rolfe, R. D. (2002). The role of probiotic cultures in the control of gastrointestinal health. J. Nutr. 130: 396-402.

3. Wee, Y. J.; Kim, j. N. and Ryu, H. W. (2006). Biotechnology production of lactic acid bacteria and its recent applications. Food Tech. Biotechnol. 44(2): 161-172.

4. Mercenier, A.; Pavan, S. and Pot, B. (2003). Probiotic as biotheraputic agents present knowledge and futures prospects. Current pharmaceutical design. 8, 99-101.

5. Nicolle,D.;McPhee,S.J.;PignoneM.;Detmer,W.M.and chou ,T.M.(2002). Pocket guide to diagnostic test,3th ed.,8 -8135-8385,lang. Medical books /McGraw-Hill.

6. Stamm ,W.E and Hooton, T.M. (1993).Management of urinary tract infections in adults. N .Engl. .J .Med;329:1328-34

7. AL-Thwani ,A.N. (2002) . Study the role of some predisposing factors for infection with Candida albicans . Iraqi J. of Science, Vol: 43 No: 12.pp 105-193.

8. Kreger-Van R. (1984): The Yeasts: a taxonomic study. $\left(3^{\text {rd }}\right.$ ed $)$, Elsevier Science Publishers B.V., Amsterdam, The Netherlands.

9. Nyirjesy, P. ; Seeney, S. M.; Grody, M. H.;Jordan ,C.A. And Buckley,H.R.(1995).Chronic fungal vaginitis:The Value of cultures .Amer.J.Obstet.Gynecol.;173:820- 823 .

10. Evans, E. and Richardson, M. (1989): Medical mycology" a practical approach" IRI press, U.K. 
11. Forbes, B. A.; Sahm , D. F.; and Wessfeld , A. S. (1998) . Bailey and Scott's Diagnostic Microbiology. $10^{\text {th }}$ ed . Mosby Inc, St.Louis. pp. 870-951.

12. Kandler, O. and Weiss, N. (1986).Genus Lactobacillus In: Bergey's Manual of Systematic Bacteriology.Eds by Sneathy, P.H.A. ; Mair, N.S. and Holt, J.G.,William and Wilkins Co. Baltimore.MD.Vol.2.1208-1234.

13. Teuber, M. (1995): The genus Lactococcus. In: The Genera of Lactic Acid Bacteria. eds. Wood, B. J. B.; Holzapfel, W. H and Blackie A . P. Chapman and Hall, U.S.A.

14. Atlas, R.M. ; Parks, L.C. and Brown, A.E.(1995). Laboratory manual of experimental microbiology. $1^{\text {st }}$ ed. Mosby-Year Book. Inc. U.S.A.

15. Holzapfel, W.H.; Haberer, P.; Snel, J.; Schillinger, U. and Huisin't Veld, J.H. (1997) Overview of gut flora and probiotics. Int J Food Microbiol 41:85-101.

16. Jawetz, E.; Melnick, J. L. and Adelberg, E. A. (1998): Review of Medical Microbidogy. $21^{\text {th }}$ edition. Appletion and Lange. USA

17. AL-Kafaji , Z. M.(1992) . Influence of various condation on Inhibitory effect of intestinal Lactobacillus against intestinal bacteria causes diarrhea. Iraqi J. of Science , Vol: 3 No:1 pp:18-26

18. Lewus , C.B. ; Kaiser , A. and Montville , T.J. (1991). Inhibition of food - borne bacterial pathogens by bacteriocins from lactic acid bacteria isolated from meat. J.Appl Environ. Microbiol., 57:1683-1688

19. Vignolo, G.M.; Suriani, F.; Holgado, A. and Oliver, G.(1993). Antibacterial-activity-of-Lactobacillus-strains-isolated-from-dryfermented sansnges.J. App. Bac., 75 : 344-349 .

20. Mazulli, T.; Simor, A.E. and Low, D.E.( 1996) Reproducibility of interpretation of Gram stained vaginal smears for the diagnosis of bacterial vaginosis. J Clin Microbiol; 28 (7): 1506-1508.

21. Vazques, J.A. and Sobel ,J.D..( 2000). Mucosal Candidiasis. Infect. Dis. Clin. N.Am.;16:793-820.

22. Baron, E.J. and Finegold, S.M. (1990). Diagnostic Microbiology: Laboratory Methods in Basic Mycology. $8^{\text {th }}$ edition. PP: 748- 775. C.V. Mosby Company.

23. Boonnaert,C.J. and Rouxhet,P.G.(2000).Surface of lactic acid bacteria:relationships between chemical composition and physic-chemical properties. App. Environ. Microbial. 66:2548-2554.

24. Simin, N. M. and Woel-Kyu, H. (2000): Immunologic effects of yogurt. The American J. of Clinical Nutrition; 71 (4), 861-872.

25. Niku-Paavola, M.-L.; Laitila, A.;Mattila-Sandholm, T. and Haikara, A. (1999). New types of antimicrobial compounds produced by Lactobacillus plantarum. J. Appl. Microbiol. 86, 29-35.

26. Fang ,W.;Shi,M.;Huany, L.;Chen,J.and Wag, Y. ( 1996 ) Antagonism of lactic acid bacteria towards Staph.aureus and E.coli on agar plates and milk.Vet.J.27(1):3-12.

27. Kubba,M.A.(2006).Improvement of inhibition efffct of probiotic against some bacterial isolate using prebiotic.MSc thesis.AL-Nahrain University

28. Yang, Z. (2000): Antimicrobial compounds and extracellular polysaccharides produced by lactic acid bacteria: structures and properties. Department of Food Technology, University of Helsinki. 
29. Jack , R.W. ; Tagg , J.R. and Ray , B.(1990).Bacteriocin of Gram positive bacteria. Microbiological Reviews.59 (2):171-200.

30. AL-Asady , A.; Farj,M.K.. and AL-Thwani, A.N.(1999). Study of inhibitory effect of Lactobacillus on Candida albicans . The Veterinarian, Vol: 9 (3) 165-184. 